\title{
KEMAMPUAN PEMBUKTIAN MATEMATIKA BERDASARKAN GENDER DAN GAYA BELAJAR
}

\author{
${ }^{1}$ Ni Ketut Erawati, ${ }^{2}$ Ni Kadek Rini Purwati \\ Pendidikan Matematika, FPMIPA, IKIP PGRI Bali, Jl. Seroja, Tonja, Denpasar Utara, Indonesia \\ e-mail: erawatiniketut294@gmail.com
}

\begin{abstract}
Abstrak
Gender dan gaya belajar memiliki peran dalam belajar matematika. Penelitian ini bertujuan untuk menganalisis adakah perbedaan kemampuan pembuktian matematika berdasarkan gender dan gaya belajar. Penelitian ini merupakan penelitian komparatif dengan rancangan faktorial yang dilaksanakan di salah satu perguruan tinggi di Bali dengan subjek penelitian mahasiswa semester VII sebanyak dua kelas yang terdiri dari 33 mahasiswa. Pengumpulan data gender dan gaya belajar menggunakan angket, sedangkan data kemampuan pembuktian menggunakan tes pembuktian dalam mata kuliah analisis riil. Data yang diperoleh dianalisis dengan ANAVA dua arah. Hasil penelitian menunjukkan terdapat perbedaan kemampuan pembuktian di antara mahasiswa perempuan dan laki-laki serta perempuan memperoleh hasil yang lebih baik. Sedangkan berdasarkan gaya belajar, secara umum menunjukkan terdapat perbedaan kemampuan pembuktian di antara gaya belajar visual, auditori, dan kinestetik. Uji lanjut menunjukkan perbedaan yang signifikan terjadi antara gaya belajar visual dan kinestetik. Hasil analisis juga menunjukkan tidak terjadi interaksi antara gender dan gaya belajar dalam mempengaruhi kemampuan pembuktian matematika mahasiswa.
\end{abstract}

Kata Kunci: Pembuktian matematika, Gender, Gaya belajar

\begin{abstract}
Gender and learning styles have a role in learning mathematics. This study aims to analyze whether there are differences in mathematical prove ability based on gender and learning styles. This research is a comparative study with a factorial design conducted at one of the univesities in Bali, with a seventh-semester sample consisting of 33 students. Data collection of gender and learning styles used questionnaires while data of prove ability used tests. The data obtained were analyzed with two-way ANOVA. The results showed there were differences in the ability of proof between female and male students where women got better results. Whereas, based on learning styles, it generally showed there are differences in the abilities of proof between visual style, auditory, and kinesthetic learning styles. Further tests showed a significant difference between visual and kinesthetic. The analysis also showed that there is no interaction between gender and learning style in influencing students' mathematical proof ability.
\end{abstract}

Keywords: Mathematical proof, Gender, Learning style.

\section{PENDAHULUAN}

Pembelajaran matematika tidak hanya belajar menghitung suatu nilai dengan rumus yang ada, tetapi juga terdapat unsur pembuktian di dalam matematika. Belajar tentang pembuktian sebenarnya telah mulai dimunculkan di tingkat sekolah menengah, tetapi bukan menjadi fokus yang utama dalam belajar matematika. Namun begitu memasuki belajar matematika di tingkat universitas, kegiatan pembuktian matematika tidak bisa dihindari, karena terdapat beberapa mata kuliah dalam matematika yang lebih banyak memiliki konsep yang abstrak dan menuntut mahasiswa untuk menunjukkan bukti dari hasil yang diperoleh, bukan menghitung untuk mendapatkan hasil. Pendidik matematika di seluruh dunia telah menganjurkan bukti itu menjadi bagian dari pengalaman matematika semua siswa (Lesseig, 2016). 
Pembuktian matematika dapat dilakukan dengan beberapa metode pembuktian sederhana dengan menggunakan aturan-aturan logika dasar, misalnya bukti langsung, bukti tak langsung, bukti dengan kontradiksi, bukti ketunggalan, penyanggahan bukti dengan counter example, serta bukti dengan induksi matematika. Tentunya sebelum melakukan pembuktian, mahasiswa harus memahami langkah-langkah yang harus dilakukan dalam setiap metode yang digunakan, serta dapat menganalisis metode yang tepat yang harus digunakan. Kemampuan yang diukur dalam penelitian ini adalah kemampuan pembuktian dalam hal membaca bukti dan mengkonstruksi bukti.

Kemampuan membaca bukti matematis seorang mahasiswa adalah ketika mahasiswa tersebut dapat mengemukakan gagasan/ide yang termuat dalam bukti tersebut baik secara lisan maupun tulisan dengan menggunakan bahasanya sendiri dan memahami apa yang termuat dalam bukti matematis tersebut (Suryana, 2015). Sedangkan kemampuan mengkonstruksi bukti adalah kemampuan seorang mahasiswa dalam menyusun bukti berdasarkan definisi dan aksioma sebelumnya yang telah diyakini kebenarannya. Serta kemampuan memvalidasi bukti adalah kemampuan seseorang dalam menunjukkan kebenaran ataupun kesalahan dalam suatu pembuktian yang diberikan.

Kesulitan-kesulitan yang dihadapi mahasiswa dalam mengkonstruksi bukti di antaranya: memahami konsep matematika, bahasa dan simbol matematika, strategi bukti matematis, dan membaca bukti (Mujib, 2019). Kesulitan yang dialami masing-masing individu tentunya bergantung pada proses belajar yang dilakukan oleh individu tersebut. Setiap individu memiliki kecenderungan cara belajar masing-masing yang disebut sebagai gaya belajar. Ada individu yang lebih cepat belajar dengan mendengarkan penjelasan, ada yang lebih cepat belajar dengan melihat langsung dan ada yang lebih cepat belajar dengan melakukan, ataupun kombinasi dua atau tiga kecenderungan tersebut.

Salah satu karakteristik belajar yang berkaitan dengan menyerap, mengolah, dan menyampaikan informasi adalah gaya belajar individu. Santrock menyatakan bahwa gaya belajar merupakan cara yang dipilih seseorang untuk menggunakan kemampuannya, sedangkan Sukadi mengungkapkan bahwa gaya belajar yaitu kombinasi antara cara seseorang dalam menyerap pengetahuan dan cara mengatur serta mengolah informasi atau pengetahuan yang didapat (Papilaya \& Huliselan, 2016).

De Poter dan Hernacki menjelaskan secara umum gaya belajar manusia dibedakan ke dalam tiga kelompok besar, yaitu gaya belajar visual, gaya belajar auditorial dan gaya belajar kinestetik (Papilaya \& Huliselan, 2016). Gaya belajar visual adalah gaya belajar dengan cara melihat, mengamati, memandang, dan sejenisnya. Gaya belajar auditorial adalah gaya belajar 
dengan cara mendengar. Gaya belajar kinestetik adalah gaya belajar dengan cara bergerak, bekerja, dan menyentuh, maksudnya ialah belajar dengan mengutamakan indra perasa dan gerakan-gerakan fisik.

Adanya perbedaan karakteristik dalam setiap gaya belajar nantinya akan mempengaruhi kemampuan matematika mahasiswa dalam belajar. Hasil penelitian Karim (2014) menunjukkan bahwa gaya belajar siswa yang berbeda akan memberikan kemampuan berpikir yang berbeda pula. Hasil penelitian Widyawati (2016) juga menyatakan bahwa terdapat pengaruh gaya belajar terhadap prestasi belajar (IPK) mahasiswa. Selain faktor gaya belajar, tentunya ada banyak faktor lain yang mempengaruhi kemampuan matematika seseorang. Salah satu faktor internal lain yang terlihat biasa tetapi tidak kalah penting dalam mempengaruhi kemampuan matematika adalah faktor gender.

Beberapa hasil penelitian menunjukkan adanya faktor gender dalam matematika karena perbedaan biologis pada otak anak laki-laki dan perempuan (Kusumawati \& Nayazik, 2017). Perempuan umumnya memperhatikan hal-hal yang konkret, praktis, emosional, dan pribadi, sementara laki-laki fokus pada hal-hal yang berorientasi secara intelektual, abstrak, dan obyektif. Dalam hal kemampuan antara laki-laki dan perempuan sebenarnya tidak ada perbedaan mendasar, tetapi perbedaannya terletak pada sikap. Perbedaan sikap ini juga terjadi dalam menerapkan strategi pembelajaran (MZ, 2013).

Masih banyak faktor internal yang mempengaruhi kemampuan belajar matematika seseorang. Kemampuan tersebut dapat berupa kemampuan pemecahan masalah, komunikasi matematis, pembuktian, serta kemampuan-kemampuan lainnya. Penelitian-penelitian sebelumnya hanya melihat faktor pengaruh gaya belajar terhadap kemampuan matematika atau peran gender dalam kemampuan matematika. Sedangkan pada penelitian ini akan membahas kedua faktor tersebut secara sekaligus dan berfokus pada kemampuan yang berkaitan dengan pembuktian matematika. Oleh karena itu penelitian ini bertujuan untuk menganalisis perbedaan kemampuan pembuktian matematika berdasarkan gender dan gaya belajar mahasiswa.

\section{METODE PENELITIAN}

Penelitian ini merupakan penelitian komparatif. Penelitian dilaksanakan di salah satu perguruan tinggi di Bali dengan populasi seluruh mahasiswa pendidikan matematika di perguruan tinggi tersebut tahun 2019. Pengambilan sampel menggunakan purposive sampling dan diperoleh mahasiswa semester VII sebanyak dua kelas sebagai kelas sampel dengan jumlah 33 mahasiswa. Pengumpulan data gender dan gaya belajar menggunakan angket. Angket gaya 
belajar terdiri dari beberapa pertanyaan dan pilihan jawaban yang dibuat sesuai karakteristik dari tiga gaya belajar yang dinyatakan oleh DePorter, et al (Sari, 2014). Sedangkan data kemampuan pembuktian matematika dikumpulkan melalui tes yang memuat soal tentang pembuktian dalam mata kuliah analisis riil. Adapun indikator yang digunakan dalam menetapkan skor dalam penilaian terhadap kemampuan pembuktian mahasiswa adalah indikator kemampuan membaca bukti dan indikator kemampuan mengkonstruksi suatu bukti yang dijelaskan pada Tabel 1.

Tabel 1. Indikator Pembuktian Matematika

\begin{tabular}{|c|c|}
\hline Kemampuan & Indikator \\
\hline Kemampuan membaca bukti (Mujib, 2019) & $\begin{array}{l}\text { 1. Kemampuan menerapkan tahapan-tahapan } \\
\text { pembuktian pernyataan ke dalam pernyataan } \\
\text { lain yang serupa. } \\
\text { 2. Kemampuan menggunakan definisi sebagai } \\
\text { acuan dalam memberikan alasan terkait } \\
\text { langkah pembuktian yang benar atau } \\
\text { perbaikan terkait simbol, narasi, premis jika } \\
\text { tahapan bukti kurang tepat. } \\
\text { 3. Membuat suatu hipotesis (konjektur) } \\
\text { berdasarkan pola dan sifat dari beberapa } \\
\text { pernyataan dan membuktikan konjektur yang } \\
\text { diperoleh tersebut secara deduktif. }\end{array}$ \\
\hline $\begin{array}{l}\text { Kemampuan mengkonstruksi suatu bukti } \\
\text { (Darmawan, 2017) }\end{array}$ & $\begin{array}{l}\text { 1. } \begin{array}{l}\text { Kemampuan mengorganisasikan } \\
\text { memanipulasi fakta-fakta, }\end{array} \\
\text { mengurutkan langkah-langkah bukti yang } \\
\text { diberikan untuk konstruksi bukti yang valid. } \\
\text { 2. Kemampuan membuat kaitan antara fakta- } \\
\text { fakta yang diketahui dalam pernyataan } \\
\text { dengan unsur-unsur yang hendak dibuktikan. } \\
\text { 3. Kemampuan menggunakan premis, definisi, } \\
\text { atau teorema-teorema yang terkait } \\
\text { pernyataan untuk membangun suatu } \\
\text { pembuktian. }\end{array}$ \\
\hline
\end{tabular}

Data yang diperoleh dianalisis menggunakan uji ANAVA dua arah. Pengujian ini bertujuan untuk melihat pengaruh dari masing-masing variabel bebas, yaitu gender dan gaya belajar, terhadap variabel terikat, yaitu kemampuan pembuktian matematika, serta pengaruh interaksi kedua variabel bebas terhadap kemampuan pembuktian matematika.

\section{HASIL DAN PEMBAHASAN}

Berdasarkan data yang diperoleh dalam penelitian ini, dapat diketahui bahwa terdapat perbedaan gaya belajar di antara mahasiswa semester VII dan jumlah mahasiswa yang memiliki gaya belajar visual adalah paling dominan. Pada Tabel 2 disajikan rekapitulasi data 
dari jumlah serta rata-rata skor kemampuan pembuktian (KP) mahasiswa berdasarkan gender dan gaya belajarnya.

Tabel 2. Rekapitulasi Jumlah dan Rata-Rata Skor KP Mahasiswa Berdasarkan Gender dan Gaya Belajar

\begin{tabular}{clrr}
\hline Gender & Gaya Belajar & Rata-Rata Skor KP & N \\
\hline Perempuan & Visual & 71,4250 & 12 \\
& Auditori & 66,34 & 5 \\
& Kinestetik & 60,6833 & 6 \\
& Total & 67,5174 & 23 \\
\hline \multirow{2}{*}{ Laki-laki } & Visual & 58,6667 & 6 \\
& Auditori & 54,8 & 1 \\
& Kinestetik & 44,1667 & 3 \\
& Total & 53,93 & 10 \\
\hline & Visual & 67,1722 & 18 \\
& Auditori & 64,4167 & 6 \\
& Kinestetik & 55,1778 & 9 \\
& Total & 63,4 & 33 \\
\hline
\end{tabular}

Berdasarkan Tabel 2 menunjukkan bahwa mahasiswa perempuan dan gaya belajar visual lebih mendominasi jumlah sampel. Dilihat dari perbedaan gender secara keseluruhan menunjukkan mahasiswa perempuan memiliki rata-rata skor kemampuan pembuktian yang lebih tinggi dari mahasiswa laki-laki. Selanjutnya dilihat dari gaya belajarnya, mahasiswa dengan gaya belajar visual memiliki rata-rata skor paling tinggi dibanding gaya belajar auditori dan kinestetik.

Berdasarkan perbedaan skor yang diperoleh dan disajikan pada Tabel 2, selanjutnya dilakukan uji secara statistik untuk melihat apakah perbedaan tersebut signifikan atau tidak dengan ANAVA dua arah berbantuan IBM SPSS Statistics 22. Sebelum melakukan uji ANAVA dilakukan uji prasyarat yaitu uji normalitas dan homogenitas. Hasil uji normalitas menunjukkan nilai sig dari Standardized Residual sebesar 0,2 yang berarti memenuhi syarat normalitas. Sedangkan hasil uji homogenitas menunjukkan nilai sig. 0,201 yang berarti memenuhi syarat homogenitas.

Uji prasyarat telah terpenuhi selanjutnya dilakukan uji ANAVA dua arah untuk melihat pengaruh gender, gaya belajar serta interaksi gender dan gaya belajar terhadap kemampuan pembuktian matematika mahasiswa. Adapun hasil yang diperoleh ditampilkan pada Tabel 3.

Tabel 3. Hasil Uji ANAVA Dua Arah

\begin{tabular}{lccrrr}
\hline Source & $\begin{array}{c}\text { Type III Sum } \\
\text { of Squares }\end{array}$ & Df & \multicolumn{1}{c}{$\begin{array}{c}\text { Mean } \\
\text { Square }\end{array}$} & \multicolumn{1}{c}{ F } & Sig. \\
\hline Corrected Model & $2178.457^{\mathrm{a}}$ & 5 & 435.691 & 3.472 & .015 \\
Intercept & 65022.643 & 1 & 65022.643 & 518.179 & .000 \\
Gender & 854.289 & 1 & 854.289 & 6.808 & .015 \\
Gaya & 849.734 & 2 & 424.867 & 3.386 & .049 \\
Gender * Gaya & 23.302 & 2 & 11.651 & .093 & .912 \\
\hline \multicolumn{5}{r}{} \\
& Kemampuan pembuktian matematika berdasarkan gender dan gaya belajar
\end{tabular}




\begin{tabular}{lrll} 
Error & 3388.043 & 27 & 125.483 \\
Total & 138211.980 & 33 & \\
Corrected Total & 5566.500 & 32 & \\
\hline
\end{tabular}

Hasil pada Tabel 3 menunjukkan nilai sig. sebesar 0,015 <0,05 untuk variabel gender, dimana 0,05 adalah nilai alpha yang ditetapkan dalam penelitian. Hal ini berarti terdapat perbedaan kemampuan pembuktian matematika berdasarkan gender antara mahasiswa laki-laki dan perempuan. Dengan kata lain terdapat pengaruh gender terhadap kemampuan pembuktian matematika mahasiswa. Hasil penelitian ini didukung oleh kesimpulan yang diperoleh Rahayuningsih dan Feriyanto (2018) yang menunjukkan bahwa perbedaan gender mempengaruhi proses berpikir mahasiswa dalam memecahkan masalah. Hasil penelitian ini sejalan dengan hasil penelitian Chusna (2015) yang menyimpulkan bahwa ada perbedaan proses berpikir mahasiswa laki-laki dan perempuan dalam memecahkan masalah pembuktian sehingga perbedaan gender menunjukkan adanya keberagaman tentang peran gender dalam pembelajaran matematika.

Perbedaan gender merupakan faktor yang mempengaruhi proses berpikir. Tetapi NAPLAN (National Assessment Program-Literacy and Numeracy) mengemukakan bahwa anak laki-laki mengalahkan anak perempuan pada berhitung dan anak perempuan secara konsisten mengalahkan laki-laki dalam membaca, menulis, dan mengeja serta tata bahasa (Leder, 2019). Berdasarkan pernyataan NAPLAN menunjukkan bahwa laki-laki lebih unggul dalam melakukan perhitungan matematika, tetapi pada penelitian ini tes yang digunakan adalah pembuktian matematika, bukan menghitung hasil dalam permasalahan matematika, sehingga yang diperlukan adalah kemampuan dalam bahasa dan menulis sesuai dengan keunggulan yang dimiliki perempuan.

Melakukan pembuktian matematika terlebih lagi dalam hal mengkonstruksi bukti matematika merupakan bagian dari suatu penemuan bukti dalam matematika. Oleh karena itu hasil penelitian ini juga didukung dengan penelitian Erawati (2019) yang menunjukkan berdasarkan pengamatan pada pembelajaran dengan model inkuiri, kemauan mahasiswa perempuan untuk belajar lebih baik dan keingintahuan mahasiswa perempuan lebih tinggi sehingga hasil belajar mahasiswa perempuan lebih tinggi daripada laki-laki dan perbedaannya signifikan. Pada penelitian tersebut menggunakan model pembelajaran inkuiri, di mana mahasiswa menggali pengetahuannya untuk menemukan konsep yang harus dipahami. Penelitian tersebut sejalan dengan penelitian ini karena dalam mengkonstruksi bukti, seseorang harus menggali sendiri pengetahuannya untuk menemukan suatu bukti. Kunci dari penemuan adalah kemauan dan keingintahuan yang tinggi seperti yang dimiliki oleh mahasiswa 
perempuan. Sehingga hasil yang diperoleh mahasiswa perempuan dalam kemampuan pembuktian juga lebih baik.

Berdasarkan hasil jawaban mahasiswa dalam mengerjakan tes kemampuan pembuktian dalam mata kuliah analisis riil dan sesuai dengan cara berpikir mahasiswa perempuan yang telah dijabarkan oleh NAPLAN sebelumnya, menunjukkan pekerjaan mahasiswa perempuan lebih teliti dan mampu memberikan penjelasan yang lebih lengkap dalam pembuktian matematika sesuai indikator pembuktian yaitu mulai dari penerapan tahapan yang harus dilakukan, mengaitkan antara fakta-fakta yang diketahui dalam pernyataan dengan unsur-unsur yang hendak dibuktikan dan memilih metode yang tepat. Tetapi semua mahasiswa mengalami kendala terutama dalam memilih definisi atau fakta yang harus digunakan dalam melakukan pembuktian dan menyelesaikan langkah pembuktian yang telah dibuat, serta kekurangan dalam membuat kesimpulan akhir yang valid dari apa yang ingin dibuktikan. Melihat kelemahan ini, dosen sebagai pengampu mata kuliah dapat memberikan bimbingan yang lebih detail mengenai apa yang harus dipahami dalam melakukan pembuktian matematika khususnya pada mata kuliah analisis riil.

Hasil pada Tabel 3 untuk variabel gaya belajar menunjukkan nilai sig. sebesar 0,049< 0,05. Hal ini berarti terdapat perbedaan kemampuan pembuktian matematika mahasiswa ditinjau dari gaya belajar. Perbedaan kemampuan pembuktian matematika berdasarkan gaya belajar menunjukkan mahasiswa dengan gaya belajar visual memiliki rata-rata skor paling tinggi, disusul oleh mahasiswa dengan gaya belajar auditori dan gaya belajar kinestetik memiliki rata-rata skor paling rendah. Hasil ini didukung oleh penelitian Widyawati (2016) yang menyatakan bahwa terdapat pengaruh gaya belajar terhadap prestasi belajar (IPK) mahasiswa. Oleh karena terdapat perbedaan yang signifikan pada variabel gaya belajar, maka selanjutnya akan dilakukan uji lanjut berupa uji Tukey untuk melihat perbedaan kemampuan pembuktian matematika di antara ketiga gaya belajar. Hasil uji Tukey ditampilkan di bawah ini dalam Tabel 4.

Tabel 4. Hasil Uji Tukey

\begin{tabular}{llc}
\hline Gaya Belajar & Gaya Belajar & Sig \\
\hline Visual & Auditori & 0,861 \\
& Kinestetik & $0,037^{*}$ \\
\hline Auditori & Visual & 0,861 \\
& Kinestetik & 0,278 \\
\hline Kinestetik & Visual & $0,037^{*}$ \\
& Auditori & 0,278 \\
\hline
\end{tabular}


Hasil uji lanjut pada Tabel 4 menunjukkan tingkat signifikansi perbedaan kemampuan pembuktian antar gaya belajar. Perbedaan yang terjadi dianggap signifikan jika nilai sig. yang ditunjukkan antar gaya belajar yang berbeda kurang dari 0,05 atau nilai sig. yang berisi tanda bintang. Oleh karena itu dapat dijabarkan bahwa perbedaan yang benar-benar signifikan adalah kemampuan pembuktian antara gaya belajar visual dan kinestetik. Sedangkan perbedaan kemampuan pembuktian yang terjadi antara gaya belajar visual dan auditori maupun antara gaya belajar auditori dan kinestetik adalah perbedaan yang tidak signifikan. Hasil uji lanjut sejalan dengan hasil yang ditampilkan pada Tabel 2, di mana rata-rata skor mahasiswa dengan gaya belajar visual jauh berbeda dengan kinestetik yaitu 67,1722 dan 55,1778. Dengan kata lain kemampuan pembuktian mahasiswa dengan gaya belajar visual lebih baik dari mahasiswa dengan gaya belajar kinestetik.

Widyawati (2016) lebih lanjut mengungkapkan mahasiswa dengan gaya belajar visual memiliki prestasi belajar yang sama dengan mahasiswa dengan gaya belajar auditorial, sedangkan kedua tipe gaya belajar tersebut memiliki prestasi belajar yang lebih baik dibandingkan dengan mahasiswa dengan gaya belajar kinestetik. Sedangkan dalam penelitian ini menunjukkan bahwa kemampuan pembuktian mahasiswa dengan gaya belajar auditori tidak berbeda dengan kinestetik. Hal ini bisa diakibatkan karena variabel yang diukur tidak sama persis, karena IPK adalah prestasi belajar secara keseluruhan, sedangkan pada penelitian ini berfokus pada kemampuan pembuktian matematika.

Hasil kemampuan pembuktian matematika mahasiswa yang memiliki gaya visual lebih baik dibanding gaya belajar kinestetik karena dalam belajar pembuktian yang lebih banyak dilakukan mahasiswa di kelas adalah membaca dan mendengarkan serta melihat contoh yang diberikan oleh dosen. Latihan pembuktian yang dilakukan adalah dengan duduk di kelas dengan mengingat kembali apa yang telah dilihat dan didengar serta dengan membaca kembali contoh-contoh pembuktian yang ada. Sehingga dalam pembelajaran ini yang paling diuntungkan adalah mahasiswa dengan gaya visual. Sedangkan yang paling tidak didukung adalah mahasiswa dengan gaya kinestetik yang cenderung mengingat dengan dominan melakukan gerakan yang aktif, bukan hanya duduk. Sehingga peran daya ingat dalam melihat dan mendengarkan menjadi lebih penting. Oleh karena itu yang perlu diperhatikan dalam pembelajaran di kelas yang memiliki beragam gaya belajar adalah memberi tahu subjek belajar tentang gaya belajar yang cenderung dimiliki sehingga subjek dapat memaksimalkan cara yang tepat untuk belajar (Erawati \& Putri, 2019). Serta mengkombinasikan gaya mengajar sehingga mendukung semua gaya belajar yang dimiliki mahasiswa. 
Perbedaan kemampuan pembuktian di antara mahasiswa yang memiliki perbedaan gaya belajar dikarenakan masing-masing gaya belajar memiliki kekuatan. Kekuatan gaya belajar visual terletak pada indra penglihatan. Ciri-Ciri individu yang memiliki tipe gaya belajar visual yaitu menyukai kerapian dan keterampilan, suka membuat perencanaan yang matang untuk jangka panjang, sangat teliti sampai ke hal-hal yang detil sifatnya, lebih mudah mengingat apa yang dilihat daripada yang didengar, mengingat sesuatu dengan penggambaran (asosiasi) visual, tidak mudah terganggu dengan keributan saat belajar, pembaca yang cepat dan tekun, lebih suka membaca sendiri daripada dibacakan orang lain,tidak mudah yakin atau percaya terhadap setiap masalah sebelum secara mental merasa pasti (Papilaya \& Huliselan, 2016). Kontribusi kekuatan ini dalam melakukan pembuktian matematika adalah seorang mahasiswa yang cenderung memiliki gaya belajar visual memanfaatkan kelebihannya yang berkaitan dengan kemampuan perencanaan, ketelitian dan sifat detailnya dalam mengkonstruksi bukti. Serta kemampuannya dalam membaca dan tidak mudah terganggu dapat memudahkan memahami ketika membaca suatu bukti matematika.

Individu dengan gaya belajar auditori lebih dominan dalam menggunakan indra pendengaran untuk melakukan aktivitas belajar. Ciri-Ciri individu yang memiliki tipe gaya belajar auditorial yaitu, mudah terganggu oleh keributan atau hiruk pikuk di sekitarnya, senang membaca dengan keras dan mendengarkan sesuatu, merasa kesulitan untuk menulis tetapi mudah dalam bercerita, pembicara yang fasih, lebih mudah belajar dengan mendengarkan dan mengingat apa yang didiskusikan daripada yang dilihat (Papilaya \& Huliselan, 2016). Kontribusi kekuatan ini dalam melakukan pembuktian matematika adalah seorang mahasiswa yang memiliki gaya belajar auditori memaksimalkan kemampuannya saat terjadi diskusi mengenai apa yang dipelajari, sehingga saat membaca ataupun mengkonstruksi bukti ingatan tersebut akan dipanggil kembali walaupun kadang terkendala saat memulai untuk menuliskan langkah-langkah dalam pembuktian.

Individu dengan gaya belajar kinestetik lebih mudah menangkap pelajaran apabila bergerak, meraba, atau mengambil tindakan. Ciri-ciri individu yang memiliki tipe gaya belajar kinestetik yaitu berbicara dengan perlahan, selalu berorientasi dengan fisik dan banyak bergerak, menghafal dengan cara berjalan dan melihat, menggunakan jari sebagai penunjuk ketika membaca, tidak dapat duduk diam untuk waktu lama, memungkinkan tulisannya jelek, ingin melakukan segala sesuatu (Papilaya \& Huliselan, 2016). Kontribusi kekuatan ini dalam melakukan pembuktian matematika adalah seorang mahasiswa yang cenderung bergaya belajar kinestetik memanfaatkan kemampuannya saat melakukan sesuatu, hal yang pernah dicoba akan 
lebih mudah untuk diingat, tetapi dalam hal mengkonstruksi bukti yang baru belum tentu dapat dilakukan dengan benar karena belum pernah dilakukan. Oleh karena itu ingatan mengenai apa yang pernah dibaca menjadi penentu saat membaca bukti dan mengkonstruksi bukti yang menjadi kekurangan dari individu dengan gaya belajar kinestetik.

Hasil berikutnya yang ditampilkan pada Tabel 3 adalah pengaruh interaksi antara gender dan gaya belajar terhadap kemampuan pembuktian matematika yang menunjukkan nilai sig. sebesar 0,912>0,05. Hal ini berarti tidak ada interaksi antara gaya belajar dan gender dalam pengaruhnya terhadap kemampuan pembuktian matematika. Dengan demikian kemampuan pembuktian matematika mahasiswa karena gender tidak dipengaruhi oleh gaya belajar yang dimiliki dan kemampuan pembuktian matematika mahasiswa yang memiliki gaya belajar visual, auditori dan kinestetik tidak dipengaruhi oleh gender. Lebih lanjut dapat diungkapkan untuk semua gaya belajar baik pada gaya belajar visual, auditori dan kinestetik, gender perempuan memperoleh skor kemampuan pembuktian paling tinggi. Sedangkan kemampuan pembuktian matematika mahasiswa dengan gaya belajar visual paling tinggi baik pada lakilaki maupun pada perempuan.

\section{SIMPULAN DAN SARAN}

Perbedaan gender dapat mempengaruhi kemampuan dan cara seseorang dalam berpikir. Kemampuan pembuktian matematika memerlukan kemampuan dalam berpikir bukan hanya menghitung dan menyelesaikan masalah, sehingga perbedaan gender juga memberikan perbedaan signifikan dalam hal pembuktian matematika. Perbedaan gender menunjukkan bahwa mahasiswa perempuan memiliki kemampuan pembuktian yang lebih baik dibanding mahasiswa laki-laki. Perbedaan gaya belajar juga memberikan perbedaan yang signifikan dalam kemampuan pembuktian matematika. Di mana perbedaan yang benar-benar signifikan terjadi antara gaya belajar visual dan kinestetik. Masing-masing gaya belajar memiliki kekuatan masing-masing yang dapat mendukung kemampuan belajar seseorang, tapi dalam pembuktian matematika juga diperlukan pemahaman tentang metode dan langkah-langkah pembuktian sehingga dapat melakukan pembuktian matematika yang valid. Hasil uji interaksi menunjukkan bahwa tidak terdapat interaksi antara gender dan gaya belajar dalam mempengaruhi kemampuan pembuktian matematika mahasiswa. Hal ini berarti secara bersama-sama faktor gender dan gaya belajar tidak serta merta mempengaruhi kemampuan pembuktian matematika, walaupun secara parsial masing-masing variabel gender dan gaya belajar berpengaruh terhadap kemampuan pembuktian matematika mahasiswa. 
Saran yang dapat diberikan dari hasil penelitian ini adalah perbedaan gender dan gaya belajar bukan menjadi penghalang bagi seseorang untuk mendapatkan hasil yang baik, walaupun secara teori masing-masing gender memiliki karakteristik proses berpikir masingmasing, namun yang terpenting adalah kemauan untuk belajar dan berusaha memahami apa yang dipelajari. Hal itupun dapat dilakukan dalam mempelajari melakukan pembuktian matematika dengan didukung oleh dosen pengajar yang sebaiknya menyajikan materi pembuktian dengan suasana yang mendukung semua karakteristik dari gaya belajar yang dimiliki oleh masing-masing mahasiswa.

\section{DAFTAR PUSTAKA}

Darmawan, P. (2017). Berpikir analitik mahasiswa dalam mengonstruksi bukti secara sintaksis. Jurnal Pendidikan Matematika, 2(2), 154-165. Diakses dari http://riset.unisma.ac.id/index.php/jpm/article/view/196/238

Chusna, D. S. (2015). Proses berpikir mahasiswa dalam memecahkan masalah pembuktian ditinjau dari perbedaan gender. Universitas Sebelas Maret. Diakses dari https://eprints.uns.ac.id

Erawati, N.K. (2019). Mathematics learning outcomes based on gender in the inquiry learning model. Advances in Social Science, Education and Humanities Research, 394, 264-269. Atlantis Press. From https://www.atlantis-press.com/proceedings/icirad-19

Erawati, N.K \& Putri, N.W.S. (2019). Analisis kemampuan komunikasi matematis mahasiswa dalam penyelesaian masalah ditinjau dari gaya belajar. Prosiding Senama PGRI, 1, 5059. Diakses dari https://ojs.ikippgribali.ac.id/index.php/senama

Karim, A. (2014). Pengaruh gaya belajar dan sikap siswa pada pelajaran matematika terhadap kemampuan berpikir kritis matematika. Jurnal Formatif, 4(3), 188-195. Diakses dari https://journal.lppmunindra.ac.id/index.php/Formatif/article/view/154/148

Kusumawati, R \& Nayazik, A. (2017). Kecemasan matematika siswa sma berdasarkan gender. Journal of Medives, 1, 92-99. Diakses dari http://e-journal.ivet.ac.id/index.php/matematika/article

Leder, G.C. (2019). Gender and mathematics education: an overview. In G. Kaiser, \& N. Presmeg (Eds.), Compendium for Early Career Researchers in Mathematics Education (1st ed., pp. 289-308). (ICME-13 Monographs). From https://link.springer.com/chapter/10.1007/978-3-030-15636-7_13 
Lesseig, K. (2016). Investigating mathematical knowledge for teaching proof in professional development. International Journal of Research in Education and Science (IJRES), 2(2), 253-270. From https://files.eric.ed.gov/fulltext/EJ1105101.pdf

Mujib, A. (2019). Kesulitan mahasiswa dalam pembuktian matematis: Problem matematika diskrit. Jurnal Math Education Nusantara. 2(1), 51-57. Available online at https://jurnal.pascaumnaw.ac.id/index.php/JMN

MZ, Z.A. (2013). Perspektif Gender dalam Pembelajaran Matematika. Marwah: Jurnal Perempuan, Agama Dan Gender, 12(1), 15-31. Diakses dari http://ejournal.uinsuska.ac.id/index.php/marwah/article/view/511

Papilaya, J.O. \& Huliselan, N. (2016). Identifikasi gaya belajar mahasiswa. Jurnal Psikologi Undip, 15(1). Diakses dari https://ejournal.undip.ac.id/index.php/psikologi/article/view/12992

Rahayuningsih, S. \& Feriyanto. (2018). Analisis Proses Berpikir Mahasiswa dalam Memecahkan Masalah Grup Ditinjau dari Gender. Jurnal Pendidikan, 3, 1672-1681. Diakses dari http://journal.um.ac.id/index.php/jptpp/article/view/12568

Sari, A.K. (2014). Analisis karakteristik gaya belajar vak (visual, auditorial, kinestetik) mahasiswa pendidikan informatika angkatan 2014. Jurnal Ilmiah Edutic, 1(1), 1-12. Diakses dari https://journal.trunojoyo.ac.id/edutic/article/view/395

Suryana, A. (2015). Analisis kemampuan membaca bukti matematis pada mata kuliah statistika matematika. Infinity Journal, 4(1), 84-95. Diakses dari http://ejournal.stkipsiliwangi.ac.id/index.php/infinity/article/view/74

Widyawati, S. (2016). Pengaruh gaya belajar terhadap prestasi belajar mahasiswa program studi pendidikan matematika (IAIM NU) Metro. Al-Jabar: Jurnal Pendidikan Matematika, 7(1), 107-114. Diakses dari http://103.88.229.8/index.php/aljabar/article/view/135/125 